\title{
"On-zone" and "off-zone" geomorphic features for multirisk assessment related to slope dynamics in the Icelandic fjords
}

\author{
A. Decaulne $\mathrm{D}^{1,2} \&$ Th. Saemundsson ${ }^{1}$ \\ ${ }^{I}$ Natural Research Centre of Northwest Iceland, Saudarkrokur, Iceland \\ ${ }^{2}$ GEOLAB, UMR6042-CNRS, Clermont-Ferrand, France
}

\begin{abstract}
Geomorphological studies are a useful tool for risk analysis in mountainous areas, as most of the vulnerable settlements are located within the deposit zones of various processes acting on slopes. Risk assessment related to slope dynamics in the Icelandic fjords, such as snow avalanches and debris flows, often consider the geomorphic characteristics "on-zone", i.e. in the slope above the inhabited area, from the starting zone to the first houses. However, most of the useful extreme runout distance features are no longer visible in built areas, as slope deposits have been removed from the residential areas during the building time, and later on. Indeed, these landforms are of great significance in risk analysis. Therefore, inquiries into "off-zone" geomorphic evidences, in unspoiled areas with similar lithologic, topographic and meteorologic conditions to inhabited surroundings, reveal the missing information "on-zone". Based on field investigations and using dendrogeomorphologic opportunities, it especially indicates the potential runout distance of slope dynamics that are lacking in built areas. Consequently, by transferring the data from unspoiled areas to inhabited areas, geomorphic investigations are an indicator for damage potential analysis in areas subjected to devastating multi-slope dynamics. Furthermore, the specific topography of the Icelandic fjords is prone to unexpected risk, such as local snow-avalanche induced tsunamis. This process has not yet been taken in account in risk analysis, originating "off-zone". However, it caused severe damages and loss of lives during the last century in the Icelandic fjords.

Keywords: snow avalanches, debris flows, multirisk assessment, field investigations, dendrogeomorphology, snow-avalanche induced tsunamis, Iceland, fjords.
\end{abstract}




\section{Introduction}

Among all the questions that have to be addressed to reduce the risk due to processes acting on slopes, these are the main ones: what are the threatening processes, how frequent are they, what is their furthest reach, what are the triggering factors and the threshold conditions? Identifying the processes is the easiest task, commonly carried out with geomorphological and historical approaches. Answering the others is far more problematic and requires combining several methods to get both relative and absolute spatio-temporal indicators. The main concern is to define the frequency of longest runoutdistance processes, and consequently the related damage potential, as it constitutes the higher threat for inhabitants. Knowledge of triggering factors enhances the prediction of the process release, and improves both prevention and mitigation of their devastating impacts downslope.

Along the shore of the Icelandic fjords (figure 1), the scattered communities (settlements from less than 200 to more than 2500 inhabitants) are totally or partly exposed to snow-avalanche and debris-flow hazards (and sometimes to rockfall and other landslide hazards as well), as the vulnerable settlements are located within the deposit zones of various processes acting on slopes [1]. To gather the most numerous available data concerning the spatio-temporal occurrence of the potentially damaging snow avalanches and debris flows above settlements, historical inventories [2], geomorphological and phytogeographical analysis are efficient approaches [3]. Models also figure the motion and runout distances of snow avalanches and debris flows, mostly based on mechanical flowing properties and on terrain variables along the path. To be the most efficient, these researches have to be conducted just above the threatened settlements and in undisturbed areas where the same processes are active, to obtain the most numerous data.

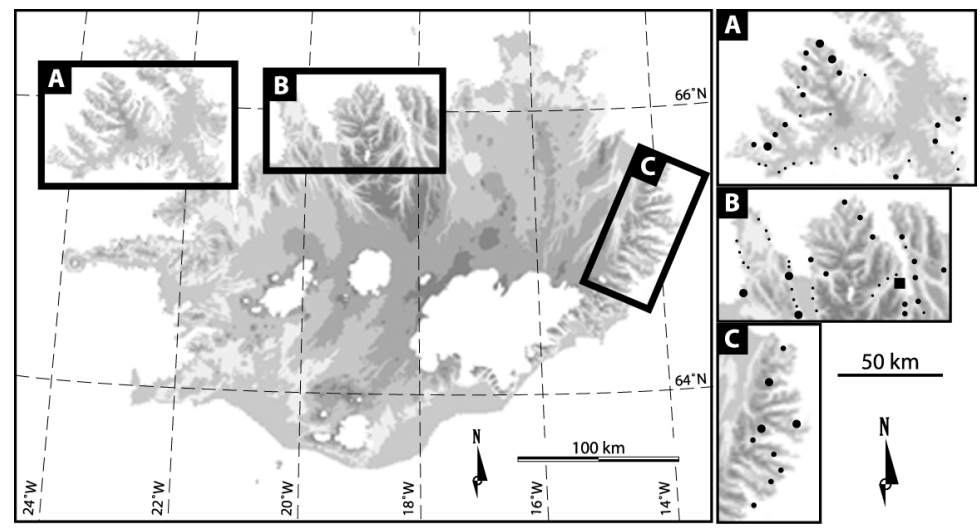

Figure 1: Location of the Icelandic fjords, and main settlements in the Westfjords (A), the Northfjords (B) and the Eastfjords (C). Square: > 7000 inhabitants; large dot: from 1000 to 3000 inhabitants; medium dot: $<200$ inhabitants; small dot: $<10$ inhabitants. 


\section{2 "On-zone" vs. "off-zone" geomorphic features}

Investigation carried out above the settlement areas are of major importance, as it highlights the propagation characteristics of the processes from the starting zone to the settlements. The distribution of typical landforms associated with snowavalanche and debris-flow activities along the different paths is most of the time the principal evidence of this activity. Moreover, the activity "on-zone" is the best documented in written material, and some reliable data on the processes runout distances could be find. Therefore, absolute and relative dating using historical and phytogeographical data could be obtained to assess the process temporal distribution. Often, several processes interact within the same slope, even within the same path, and geomorphic evidences underlines these dual/multi processes sites. It is now established that the frequency of processes acting on slopes decreases while their magnitude increases; however, the existence of recurrent low magnitude events should not push to ignore the potentiality of larger event formation. Hence, all possible source areas have to be considered. Lower parts of the paths are the most interesting ones when dealing with risk assessment: at such locations, numerous evidences have disappeared, most of them being disturbed, removed or destroyed during the spatial expansion of fjord communities, mostly during the $20^{\text {th }}$ century [4]. Especially, all superficial evidences that define the furthest reach of the processes are not longer visible. That is however the main issue, as it figures the extent of previous extreme events, those that could have not been recorded by inhabitants as the main actual fjord inhabited areas do not exist since 150 years for older permanent houses, and since 40-60 years for the settlements in its actual extend. Without the geomorphic features providing evidences of the longest runout distances, an underestimation of the hazard and risk zoning and of risk calculation is possible, as it is based on longest runout distance of recent known events, which does not match with the absolute longest runout distance. To try to provide a better risk assessment downslope, a geomorphological approach considering "off-zone" features is proposed (figure 2). Here we will focus on the observation of damages on vegetation and ground both "on-zone", i.e. above the settlement, and "off-zone" to assess the risk due to slope processes, as a complementary method to improve risk assessment.

\section{Geomorphic features "on-zone"}

In the immediate settlement surroundings, historical sources are an essential help for risk analysis. Unfortunately, such data have a time limit, as it covers only several tens years in the Icelandic fjords; therefore, the period covered by such data is short, and could be shorter than the extreme events return period. Also, written material only record events that occurred at a close distance from the settlement area, therefore the whole present-day inhabited area may not been considered by such material. Nevertheless, the advantage of such data is that longest runout distances during the observation period have probably be recorded, at least at the proximity of the oldest part of these small communities. 
Hence, the most extreme events that occurred close to the areas that were inhabited in the $20^{\text {th }}$ century are known and mapped (figure 3 ).
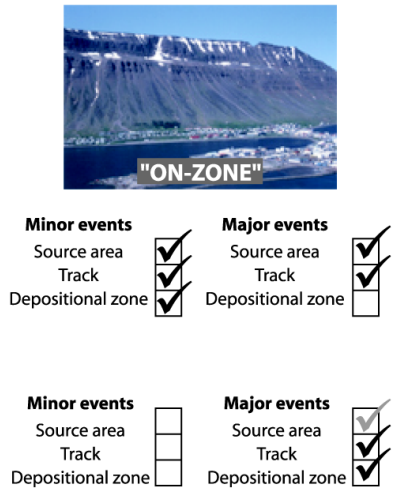

\section{RISK ASSESSMENT}

Which slope dynamics? (Process identification) Where? (Paths identification)

How frequent? (Return period identification) Which extent? (Runout distance identification) How? (Triggering factors \& theshold idenification)

\section{METHODS}

Geomorphological investigations Results

absolute spatial distribution

relative temporal distribution Limitation

Unefficient when the natural surface has been disturbed
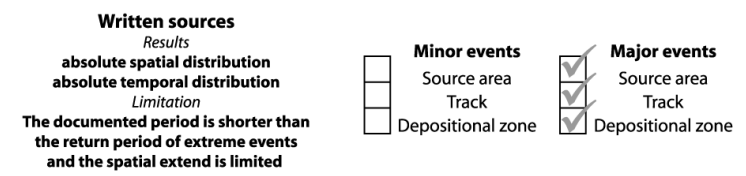
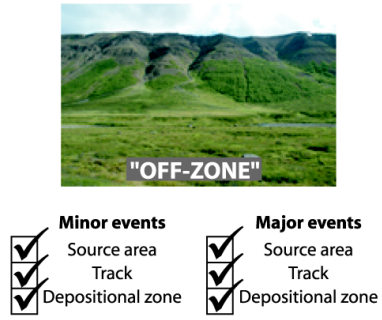

Depositional zone $\checkmark$ Depositional zone

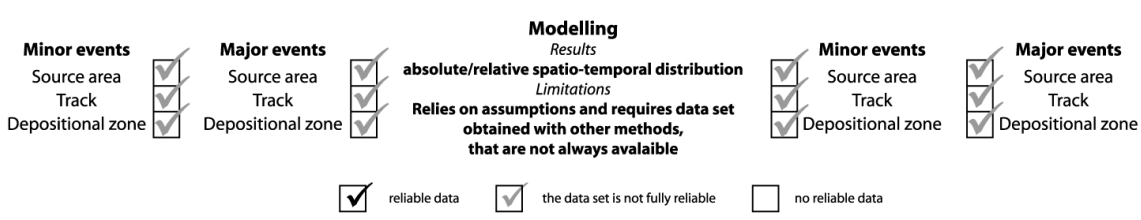

Figure 2: The "on-zone" - "off-zone" concept that underlines the necessity of geomorphological investigations out of threatened areas.

On the slopes, numerous evidences reveal the snow-avalanche and debrisflow activity, even if both processes do not have a similar geomorphic impact. For snow avalanches and debris flows, the investigation is done along the path, from the source area to the deposition zone. Morphological analyses define the starting zone for snow avalanches, most of the time at the top of the leeward slopes where deep rock wall dissections and notches are favourable snow accumulation areas. Then, the track is located in a straight line from the starting zone, and is generally unconfined, travelling through the talus slopes. When confined, the track leads to a debris cone. In the track, the presence of perched boulders reveals the geomorphic activity of snow avalanches. In the deposition zone, boulders transported by snow avalanches plough or not the slope surface and accumulate, being a clear indication of the snow-avalanche activity [5]. Several of these accumulations can be observed above settlements. The source area for debris flows depends on debris availability: it is located in the gullies that dissect the rock wall and at the edge of debris benches inherited from glacial periods. From this upper point the path of the debris flow is identifiable by a longitudinal succession of typical landforms: a gully, a gully bordered with lateral levées, and only lateral levées that lead to a debris lobe [6].

For both snow-avalanche and debris-flow risk analysis, the downslope part of the path is the most interesting, but is largely truncated (figure 3). Therefore, the only data regarding the longest runout distances are the observations done since 
few decades. It does not give many details with regard to the flow thickness or boulder removing, that could be more pertinent that the only mention of damages, which depends on the building structure and locations of windows, often large and facing the mountain side in Iceland. However, both snow avalanches and debris flows have reach in the past the present-day inhabited areas, and these documented runout distances have to be considered as minimal.

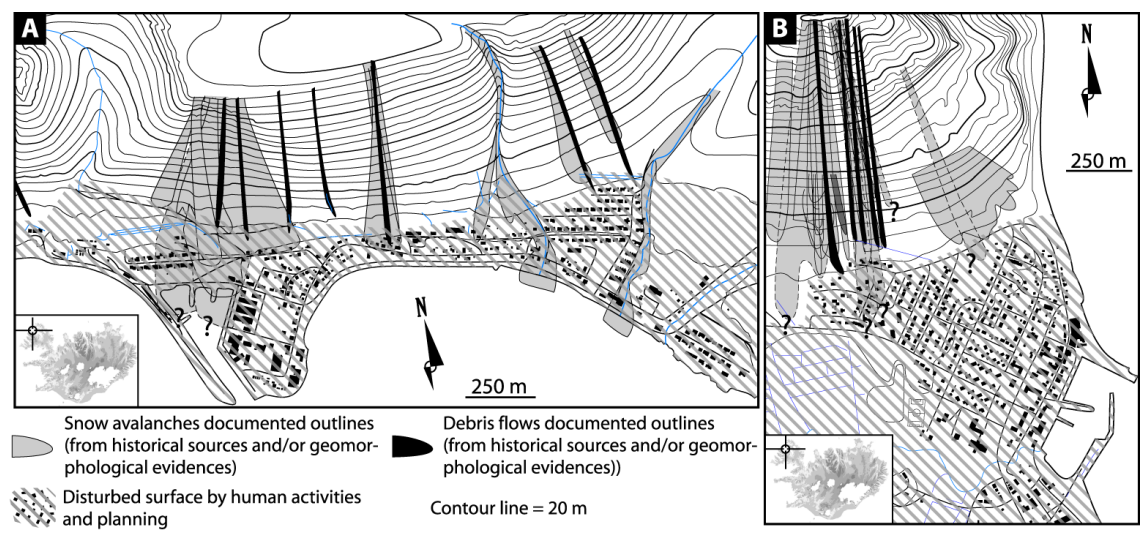

Figure 3: Disturbed surfaces "on-zone" in Patreksfjordur (A) and Bolungarvik (B) where geomorphological evidences are invisible or not fully reliable.

\section{Runout distances "off-zone"}

Remote and undisturbed or low human disturbed areas are numerous in the Icelandic fjord areas, and several of those have been studied in the north part of Iceland. The Fnjoskadalur valley is one of those. The eastern side of the valley presents several debris cones with long concave profiles and numerous accumulation of all size rock debris in the distal part, as far as several tens metres downslope the $10^{\circ}$ nick-point of the slope ( $\beta$ ). Moreover, the slopes are forested, offering a rare dendrogeomorphological opportunity on Icelandic slopes [7]. Three cones have been examined in the valley (figure 4), with topographical, sedimentological and phytogeographical investigations. Snow-avalanche transported boulders and dendrogeomorphological results are presented here, highlighting the runout distance of snow avalanches (which is further than the furthest boulders) and its lateral spreading over debris cones. The location of snow-avalanche transported boulders as far as $300-400 \mathrm{~m}$ downslope the isoline $\beta$, i.e. the position where snow avalanches decelerate, underlines the very long path of snow avalanches in site B.

Moreover, must of these boulders have been newly deposited, as their surface is bare of lichens. That means that extreme runout avalanches were active during the last 5-8 years, according to north-Iceland lichen growth curves $[8,9]$. 

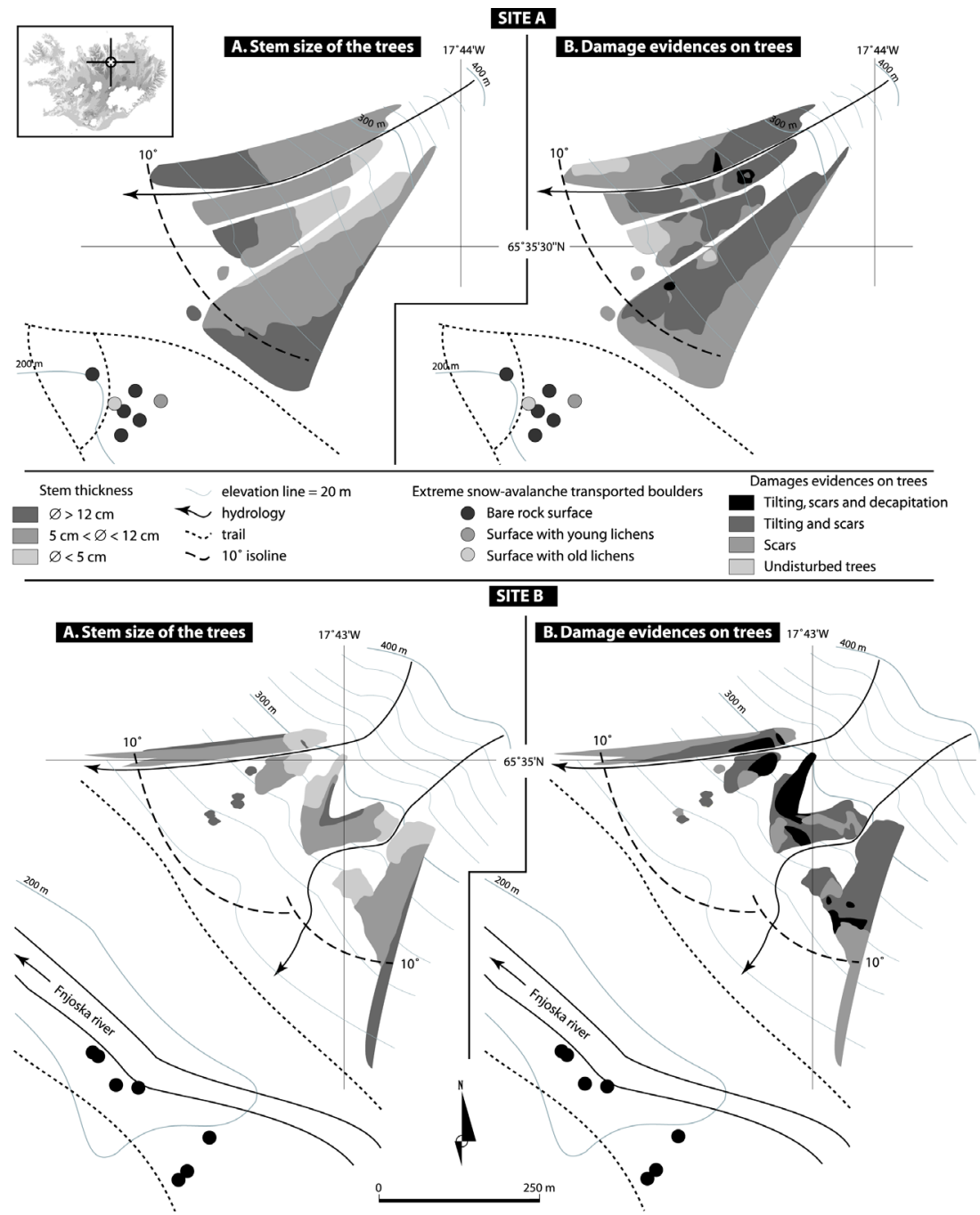

Figure 4: "Off-zone" investigations of snow-avalanche runout distance and lateral spreading by superficial geomorphological and dendrogeomorphological analyses.

The forested cover is a help for the identification of avalanche paths on slopes. The site A is far more covered than site B, indicating a weaker snow-avalanche dynamic. The more limited effect of avalanches from this path is heightened by a shorter runout distance of snow-avalanche transported boulders of only $220 \mathrm{~m}$. The tree thickness distribution on this cone underlines that the southern path is the most active, and the furthest boulders are found in its trajectory. Lower magnitude avalanches are recurrent, as indicated by the location upslope of smaller trees. If most of the trees present tilting, and tilting and scars, only few 
are decapitated. Some of these are located downslope, indicating that transported boulders are still potentially destructive far down in the path. On site B, the coalescent debris cones present thinner stems, indicating that their growth is impeded, and severe damages on trees are more widespread; smaller trees are found in the trajectory taken by most recurrent snow avalanches. The avalanche activity seems to be more efficient than in site A, as decapitated trees are more widespread, especially in the upper parts. Debris flows are also active on these cones, and participate to impede the stem growth at several locations on the cones, but are of lower extension than snow avalanches and do not reach more than 50-100 $\mathrm{m}$ from the $\beta$ isoline. The main point is that all debris flow channels originate in the same source area, and their progression downslope can follow several paths that sweep the whole debris cone.

\section{Transfer "off-zone" - "on-zone"}

Following the $\alpha / \beta$ model [10], the runout distances of snow avalanche transported boulders are calculated, by using the reference $\beta$ - and $\alpha$-angles from site $\mathrm{B}$ in the Fnjoskadalur valley; the transfer relation is:

$$
\alpha=0.78 \cdot \beta
$$

where $\beta$ is the path steepness, i.e. the slope angle from the starting zone to the position where the slope reaches $10^{\circ}$, and $\alpha$ is the slope angle from the starting zone to the furthest reach of avalanche transported boulders.
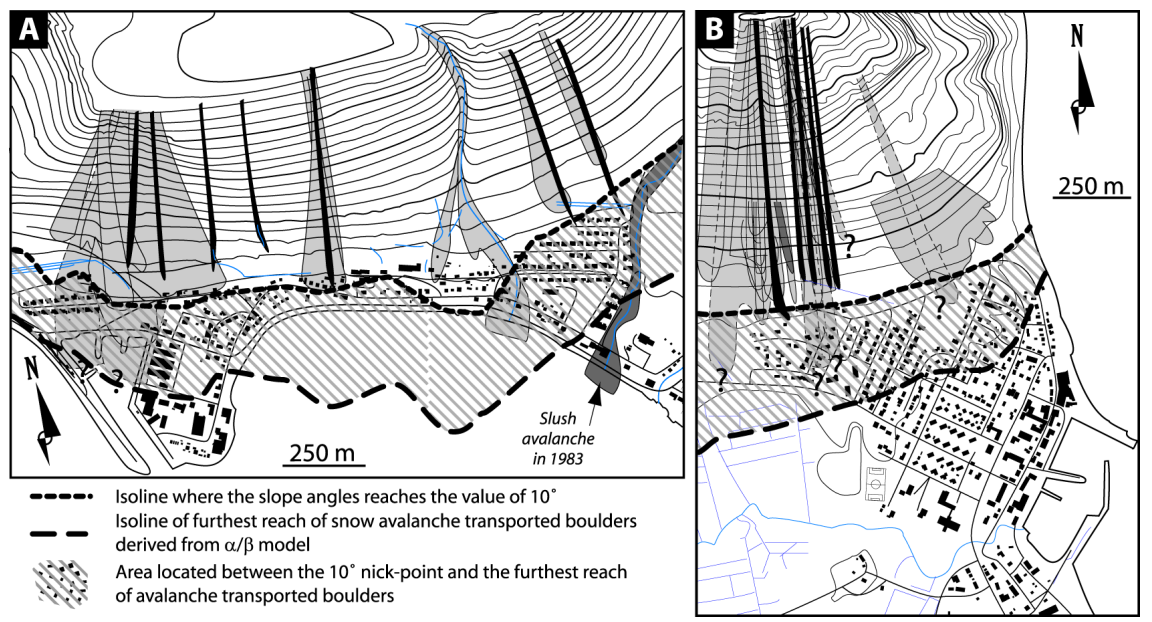

Figure 5: Furthest reach for snow avalanche transported boulders in Patreksfjordur (A) and Bolungarvik (B).

This calculation does not include the furthest reach of snow, but figures the potential extreme limits of snow avalanches transported boulders, uphill the furthest reach of the snow debris. The calculation is applied to Patreksfjordur and Bolungarvik settlements (figure 5), for which the position of $\beta$ is known $[11,12]$; 
the position of the extreme reach of avalanche boulders does not take in account the presence of buildings in the path, hence is theoretical. It figures however the damage potential from the $\beta$ isoline to the furthest reach. In the case of Patreksfjordur, the superimposition of the furthest runout distance of snowavalanche boulders with the documented extreme snow-avalanche outlines is quite relevant in the western part of the settlement, but obviously do not match with specific dynamics such as slush avalanches (figure 5A); it also indicates that damages are potentially large for buildings and inhabitants located above the $10^{\circ}$ isoline, and also between this line and the boulder further reach, as it goes through the whole inhabited area. In Bolungarvik (figure 5B), extreme snow avalanches could deposit large boulders more than $200 \mathrm{~m}$ further the longest documented runout distance; hence, it figures that the uppermost houses are located in the most threaten area. In both cases, such approach underlines that the most extreme events have still not been recorded. Researches on such long runout distance processes have to enhance the frequency issue to be more reliable.

\section{A specific risk: the avalanche-induced tsunamis}

Most of settlements in the Icelandic fjords are located along the coastline, at the foot of steep slopes that are prone to dangerous slope dynamics. The fjords are often narrow, with a perfect trough transversal profile. This specific topography leads to hazards that are not considered into recent Icelandic risk assessment. At least three times during the last two centuries occurred snow avalanches on the slope that faces the fjord communities of Siglufjordur (N Iceland) and Sudureyri (NW Iceland), impacting the sea and provoking the formation of snow-avalanche induced tsunamis that propagate to the shore and cause damages while breaking on the human infrastructures located on the other side of the fjord. The figure 6A illustrates the case of Siglufjordur, in December 1839 (severe material damages around the harbour) and April 1919 (9 deaths and severe material damages). The figure $6 \mathrm{~B}$ shows a different case of devastating waves, where their height is exacerbated by the specific topography of the fjord: in October 1995 the avalanche impacted the sea that fills the overdeepened glacial basin, several hundreds metres east from the settlement, and the waves rapidly propagated out of the basin, reaching a maximal height at the rock bar location, on which is partly built the village of Sudureyri, causing severe damages to buildings and boats in the harbour area. The longitudinal profile of the distal part of the slope determines the tsunamis formation by an avalanche, hence the formation of devastating waves. Especially, the presence of roads at the bottom of the slope breaks the velocity of the avalanche and reduces the snow volume that impacts the sea, hence reduce the wave formation. Therefore, only few communities are threatened by such tsunami hazard in the Icelandic fjords, but the risk should not be disregarded, as the time of the avalanche occurrence influence greatly the potential number of victims (the last two cases happened during the night, which limited the number of persons flooded by the waves). As well, this risk should 
not be disregarded on the several roads of the fjord that could be impacted by the snow-avalanche waves originating "off-zone".

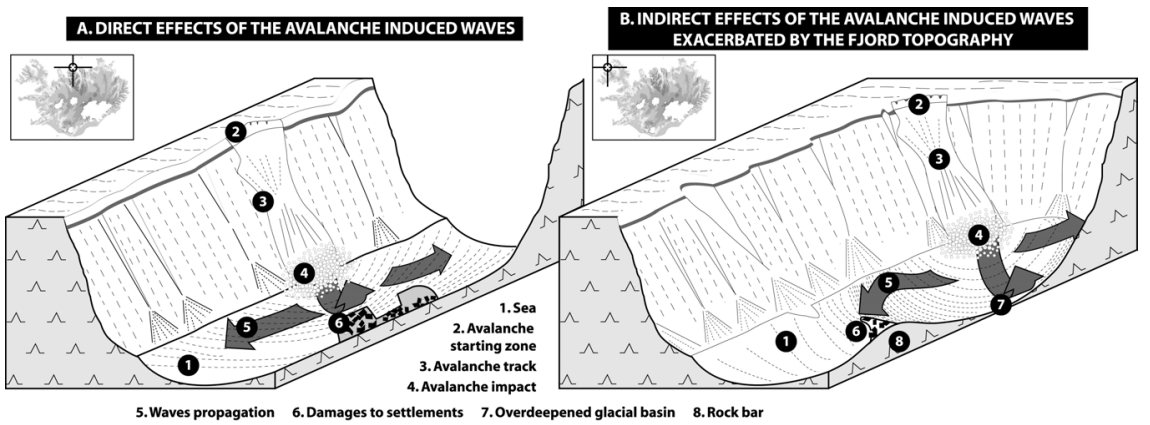

Figure 6: The snow-avalanche induced waves causing direct and indirect damages to fjord settlements, according to the location of the snow avalanche and the fjord topography.

Even if the process is infrequent, it could be potentially damaging. Further researches are needed, especially concerning the propagation speed and the height of the waves when impacting the settlements. The easiest way to reduce this risk should focus on snow stabilisation in the avalanche starting zones and on the avalanche speed reduction in the distal part of the avalanche paths that threat directly or indirectly settlements.

\section{Conclusions}

This study highlights the role of "off-zone" investigations for risk assessment, and emphasises the potential extreme runout distances of snow avalanches within inhabited areas, far longest than debris-flow ones, from geomorphological and dendrogeomorphological evidences. "On-zone" investigations are a priority above settlements that are directly threatened by several processes, to recommend the first protection and mitigation measures. "Off-zone" investigations are a second step, to gather the most numerous data and improve the knowledge of the couple slope dynamic/risk assessment. Such researches have to be regarded as an evolving process, not a static one, and should lead to the re-evaluation of previous risk assessment, according to new findings concerning magnitude and frequency of the events.

\section{Acknowledgements}

This study benefited from support by the Natural Research Centre of Northwest Iceland, the Laboratory of Physical Geography-CNRS of Clermont-Ferrand and the French Arctic Research Network. The authors are grateful to the persons in charge of these institutions. 


\section{References}

[1] Decaulne, A., Dynamique des versants et risques naturels dans les fjords d'Islande nord-occidentale, l'impact géomorphologique et humain des avalanches et des debris flows. PhD Thesis, Department of Geography, University Blaise Pascal, Clermont-Ferrand, France, 391 p.

[2] Glade, T., Landslide hazard assessment and historical landslide data - an inseparable couple? The Use of Historical Data in Natural Hazard Assessments, eds. T. Glade, P. Albini \& F. Francès, Kluwer Academic Publishers: Dordrecht, pp. 153-168, 2001.

[3] Decaulne, A., Combining geomorphological, historical and lichenometrical data for assessment of risk due to present-day slope processes, a case-study from the Icelandic Wesfjords. Risk Analysis 4, ed. C.A. Brebbia, WIT press: Southampton, pp. 177-186, 2004.

[4] Decaulne, A., Slope processes and related risk appearance within the Icelandic Westfjords during the twentieth century. Natural Hazards and Earth Science Systems, 5, 309-318, 2005.

[5] Decaulne, A. \& Saemundsson, Th., Geomorphic evidence for present-day snow-avalanche and debris-flow impact in the Icelandic Westfjords, Geomorphology, 2006 (accepted).

[6] Decaulne, A., Saemundsson, Th. \& Petursson, O., Debris flows triggered by rapid snowmelt in the Gleiðarhjalli area, northwestern Iceland. Geografiska Annaler, 87A (4), 487-500, 2005.

[7] Decaulne, A. \& Saemundsson, Th., Geomorphological investigations in the Fnjoskadalur and Bleiksmyrardalur valleys, north Iceland: snowavalanches impact on slopes. Internal report, Natturustofa Nordurlands vestra, 17 p., 2005.

[8] Decaulne, A. \& Saemundsson, Th., Debris flows characteristics in the Gleidarhjalli area, North-western Iceland. Debris-Flow Hazards Mitigation: Mechanics, Prediction, and Assessment, eds. D. Rickenman \& C.I. Chen, Millpress: Rotterdam, pp. 1107-1118, 2003.

[9] Kugelmann, O., Dating recent glacier advances in the Svarfaðardalur Skíðadalur area of northern Iceland by means of a new lichen curve, Environmental changes in Iceland: Past and Present, eds. J.K. Maizel \& C. Caseldine, Kluwer Academic Publishers: Dordrecht, pp. 203-217, 1991.

[10] Lied, K. \& Bakkehoi, S., Empirical calculation of snow avalanche run-out distance based on topographical parameters. Journal of Glaciology, 26, pp. 165-177, 1980.

[11] Agustsson, K., Johannesson, T., Sauermoser, S. \& Arnalds, Th., Hazard zoning for Bolungarvik, Technical report, Icelandic Meteorological Office, VI-UR19, 2002.

[12] Agustsson, K., Johannesson, T., Sauermoser, S. \& Sigurdsson, H.Th.: Hazard zoning for Patreksfjordur, Vesturbyggd, Technical report, Icelandic Meteorological Office, VI-UR20, 2003. 